activities of the key enzymes of gluconeogenesis in the liver and kidney of the foetal guinea pig have been followed.

The foetal guinea pigs used had a gestational age of 68-72 days. Pyruvate carboxylase was present at very low activities in the kidney of the foetus and neonatal animal and also in the foetal liver until day 50 , when it increased in activity to reach a value by day 60 of more than twice the maternal liver value. There was a rapid postnatal fall in activity. The foetal liver enzyme was largely mitochondrial, required acetyl-CoA for activity and, like the adult liver enzyme, had a $K_{m}$ for pyruvate of approx. $0.7 \mathrm{~mm}$.

Unlike the adult liver, most of the phosphopyruvate carboxylase was particulate, and the solublefraction enzyme of the foetal liver had the properties of the particulate enzyme of the adult and foetal liver. Particulate enzyme, which was largely mitochondrial, was present in significant amounts from day 35 , and by day 65 its activity was approximately threefold greater in the foetal liver than the adult liver. In both the liver and the kidney soluble-enzyme activity was low during foetal life but showed a large rise during the first 2 days after birth.

Fructose 1,6-diphosphatase was present in low activity in the foetal liver and kidney until day 40 , when its activity rapidly rose so that by day 45 it was just below the maternal enzyme activities. Foetal liver and maternal liver enzymes had similar properties, although the foetal liver enzyme was more sensitive to AMP and substrate inhibition and had a $K_{m}$ for fructose 1,6-diphosphate of $1 \mu \mathrm{M}$.

The changes in the activities of glucose 6-phosphatase were very similar to those for fructose 1,6diphosphatase. In the foetal tissues the enzyme reached an activity of about half that found in the adult, had a $K_{m}$ of $10 \mathrm{~mm}$ and was inhibited by glucose.

Auricchio, S. \& Rigillo, N. (1960) Biol. Neonatorum 2, 146

Ballard, F. J. \& Oliver, I. T. (1963) Biochim. Biophys. Acta 71, 578

Ballard, F. J. \& Oliver, I. T. (1965) Biochem. J. 95, 191

Greengard, O. \& Dewey, H. K. (1967) J. Biol. Chem. 242 , 2986

Räiha, N. C. R. \& Lindros, K. O. (1969) Ann. Med. Exp. Biol. Fenn. 47, 146

Yeung, D. \& Oliver, I. T. (1967) Biochem. J. 103, 744

Yeung, D., Stanley, R. S. \& Oliver, I. T. (1967) Biochem. J. 105, 1219

\section{Purification by Affinity Chromatography of Thermostable Glyceraldehyde 3-Phosphate Dehydrogenase from Thermus aquaticus}

\author{
By J. D. Hocking and J. IEUAN Harris (Medical \\ Research Council Laboratory of Molecular Biology, \\ Hills Road, Cambridge CB2 2QH, U.K.)
}

The mechanisms that allow enzymes of thermophilic organisms to function at high temperatures are of considerable biochemical interest (cf. Brock, 1967). In this connexion a study of glyceraldehyde 3-phosphate dehydrogenase and other glycolytic-cycle enzymes from the obligate thermophile Bacillus stearothermophilus 1503 (grown at $60^{\circ} \mathrm{C}$ ) has shown that enzymes from this source are considerably more stable towards heat and denaturing agents than are their counterparts from muscle and yeast (e.g. see Amelunxen, 1967; Suzuki \& Harris, 1971). As an extension of this work we now report the isolation and properties of glyceraldehyde 3-phosphate dehydrogenase from the more extreme thermophile Thermus aquaticus (Brock \& Freeze, 1969), which grows optimally at $70-75^{\circ} \mathrm{C}$.

Cell extracts were treated with deoxyribonuclease and stirred with DEAE-cellulose equilibrated with $10 \mathrm{~mm}$-tris- $\mathrm{HCl}$ buffer, pH7.5 (containing $\beta$-mercaptoethanol and EDTA) (cf. Atkinson et al., 1972). Material adsorbed on DEAE-cellulose was eluted by two washings with the same buffer containing successively $0.1 \mathrm{M}-$ and $0.4 \mathrm{M}-\mathrm{NaCl}$. The fraction eluted with $0.4 \mathrm{M}-\mathrm{NaCl}$ was adsorbed on hydroxyapatite in phosphate buffer, pH6.5, and the hydroxyapatite was in turn washed successively with $0.06 \mathrm{M}$ - and $0.2 \mathrm{M}$ phosphate buffer, $\mathrm{pH} 6.8$. To the latter fraction was added solid $\left(\mathrm{NH}_{4}\right)_{2} \mathrm{SO}_{4}$ to $1.2 \mathrm{M}$, and the resulting supernatant, which contained most of the glyceraldehyde 3-phosphate dehydrogenase and phosphofructokinase, was now applied to a column $(200 \mathrm{ml}$ bed volume) of $\mathrm{NAD}^{+}-$Sepharose prepared by the methods of Cuatrecasas (1970) and Weibel et al. (1971) (see also Lowe \& Dean, 1971; Mosbach et al., 1971). Phosphofructokinase activity was successfully eluted with $0.7 \mathrm{~B}-\mathrm{NaCl}$ containing $1 \mathrm{~mm}-\mathrm{ATP}$, and pure glyceraldehyde 3-phosphate dehydrogenase (in $80 \%$ yield, representing $20-30$-fold purification in this step) was subsequently eluted with $10 \mathrm{~mm}-\mathrm{NAD}^{+}$. The yield of pure enzyme was $150-200 \mathrm{mg} / 500 \mathrm{~g}$ of frozen cells, and it was crystallized directly from this solution by dialysis against $1.7 \mathrm{M}-\left(\mathrm{NH}_{4}\right)_{2} \mathrm{SO}_{4}$. The crystalline enzyme, which contained $4 \mathrm{~mol}$ of firmly bound $\mathrm{NAD}^{+} / \mathrm{mol}$, gave a single band when examined by gel electrophoresis with and without $0.1 \%$ sodium dodecyl sulphate. The molecular weight, on the basis of gel filtration on Sephadex G-200, was 150000 , and the subunit molecular weight in $0.1 \%$ sodium 
dodecyl sulphate was 36000 , indicating a tetrameric structure.

T. aquaticus glyceraldehyde 3-phosphate dehydrogenase (the apo- as well as holo-enzyme) is stable for several hours at $90^{\circ} \mathrm{C}$ (the $B$. stearothermophilus enzyme is totally inactivated within $10 \mathrm{~min}$ at this temperature) but is rapidly inactivated above $100^{\circ} \mathrm{C}$. Moreover, like the $B$. stearothermophilus enzyme (K. Suzuki \& J. I. Harris, unpublished work), it retains its activity fully after exposure to $8 \mathrm{M}$-urea and $1 \%$ sodium dodecyl sulphate. Some chemical, physicochemical and kinetic parameters of the enzyme will be presented.

We are indebted to Dr. K. Sargeant and Mr. A. R. Whitaker (Microbiological Research Establishment, Porton, Wilts., U.K.) for providing frozen cells of $T$. aquaticus.

Amelunxen, R. E. (1967) Biochim. Biophys. Acta 139, 24 Atkinson, A., Phillips, B. W., Callow, D. S., Stoner, W. R. \& Bradford, P. A. (1972) Biochem. J. 127, 63 P

Brock, T. D. (1967) Science 158, 1012

Brock, T. D. \& Freeze, H. (1969) J. Bacteriol. 98, 289

Cuatrecasas, P. (1970) J. Biol. Chem. 245, 3059

Lowe, C. R. \& Dean, P. D. E. (1971) FEBS Lett. 14, 313

Mosbach, K., Guilford, H., Larsson, P.-O., Ohlsson, R. \& Scott, M. (1971) Biochem. J. 125, 20P

Suzuki, K. \& Harris, J. I. (1971) FEBS Lett. 13, 217

Weibel, M. K., Weetall, H. H. \& Bright, H. J. (1971)

Biochem. Biophys. Res. Commun. 44, 347

\section{Metabolic Regulation in the $\mathrm{C}_{4}$ Dicarboxylic Acid Pathway of Photosynthesis}

\section{JAMES COOMBS*, CARL W. BALDRY* and ChRISTOPHER BUCKe (Tate and Lyle Ltd. Research Centre, Westerham Road, Keston, Kent BR2 6HJ, U.K.)}

We have suggested (Baldry et al., 1971) that in the tropical grasses the $\mathrm{C}_{4}$ dicarboxylic acid pathway of photosynthesis (Hatch \& Slack, 1970) is located in the cytoplasm and acts as a mechanism for concentrating $\mathrm{CO}_{2}$ at the site of reductive assimilation in the chloroplasts of the mesophyll cell layer. The initial incorporation of $\mathrm{CO}_{2}$ into $\mathrm{C}_{4}$ organic acids is catalysed by phosphopyruvate carboxylase (EC 4.1.1.31). Investigations of cytoplasmic phosphopyruvate carboxylase partially purified from leaves of the plant Pennisetum purpureum, which utilizes the $\mathrm{C}_{4}$ dicarboxylic acid pathway, suggest that this enzyme may be regulated by photosynthetic activity.

Leaf tissue $(100 \mathrm{~g})$ was homogenized in $200 \mathrm{ml}$ of chloroplast isolation medium [as described by Baldry et al. (1968), with the omission of thiols, which

* Present address: Tate and Lyle Ltd., Group Research and Development, Philip Lyle Memorial Research Laboratory, P.O. Box 58, Reading RG6 2BX, Berks., U.K. were not necessary since this plant contains very low $o$-diphenol oxidase (EC1.10.3.1) activity]. Subcellular particles were removed by centrifugation and cytoplasmic protein was precipitated with $\left(\mathrm{NH}_{4}\right)_{2} \mathrm{SO}_{4}$ (60\% saturation). The dialysed freeze-dried precipitate was dissolved in $10 \mathrm{~mm}$-tris- $\mathrm{HCl}$ buffer, $\mathrm{pH} 7.0$, applied to a column of DEAE-cellulose and eluted with a linear gradient of tris- $\mathrm{HCl}$ buffer, $\mathrm{pH}$ 7.0. Incorporation of ${ }^{14} \mathrm{C}$ into oxaloacetate, trapped as the 2,4-dinitrophenyhydrazone, was measured in reaction mixtures containing phosphoenolpyruvate, $\mathrm{Mg}^{2+}, \mathrm{H}^{14} \mathrm{CO}_{3}{ }^{-}$and enzyme in $200 \mu \mathrm{l}$ of $50 \mathrm{~mm}-$ HEPES (N-2-hydroxyethylpiperazine-N'-2-ethanesulphonic acid) buffer, pH8.0.

Variation of rate of reaction as a function of limiting concentrations of $\mathrm{HCO}_{3}{ }^{-}$or of $\mathrm{Mg}^{2+}$ approximated to first-order kinetics. However, sigmoid kinetics were observed when the rate of reaction was determined as a function of phosphoenolpyruvate concentration. Addition of intermediates of the photosynthetic carbon-reduction cycle ( $5 \mathrm{~mm}$ ) stimulated (ribose 5-phosphate, fructose 1,6-diphosphate, fructose 6-phosphate, glucose 6phosphate) or inhibited (phosphoglycerate) the reaction. The effects of glucose 6-phosphate were investigated further. Enzyme activity increased when the concentration of phosphoenolpyruvate exceeded that of glucose 6-phosphate, but was decreased when the concentration of glucose 6-phosphate exceeded that of phosphoenolpyruvate. The enzyme was also inhibited by oxaloacetate $(50 \%$ at $1.5 \mathrm{~mm})$ and malate $(50 \%$ at $6.0 \mathrm{~mm})$. In the presence of malate dehydrogenase (EC 1.1.1.37) NADH increased the rate of reaction, presumably owing to reduction of oxaloacetate to the less inhibitory malate. The increased enzyme activity observed when NADH was included in the reaction mixture was additive to that caused by glucose 6-phosphate. Activation by glucose 6-phosphate did not occur in the presence of thiols ( $\beta$-mercaptoethanol, thioglycollate, dithiothreitol, GSH, at $0.1-10 \mathrm{~mm}$ ) or $1.5 \mathrm{M}$-urea.

These results suggest that the cytoplasmic phosphopyruvate carboxylase of $P$. purpureum is an allosteric enzyme regulated by intermediates of the photosynthetic carbon-reduction cycle. In this case the initial assimilation of $\mathrm{CO}_{2}$ into oxaloacetate in plants that utilize the $\mathrm{C}_{4}$ dicarboxylic acid pathway could be regulated by the photosynthetic activity of the mesophyll chloroplasts.

Baldry, C. W., Coombs, J. \& Gross, D. (1968) Z. Pflanzenphysiol. 60, 78

Baldry, C. W., Bucke, C. \& Coombs, J. (1971) Planta 97, 310

Hatch, M. D. \& Slack, C. R. (1970) Annu. Rev. Plant. Physiol. 21, 141 